Int. J. Curr. Res. Med. Sci. (2017). 3(5): 21-28

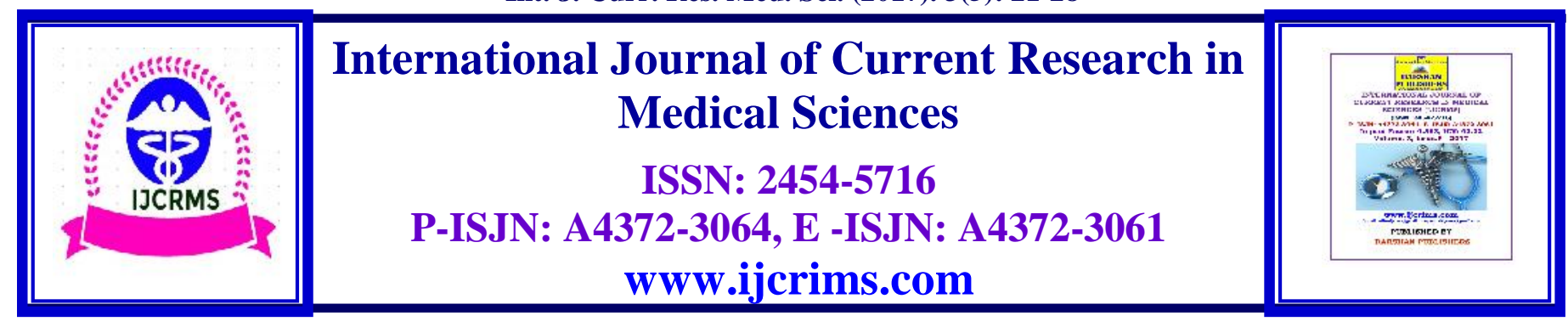

\title{
A Study to assess the knowledge and Attitude about Female Feticide among women attending outpatient department in a tertiary care hospital Punjab
}

\author{
*Harshindar Kaur, **Gurpal Singh Sachdeva \\ *Assistant Professor Pediatrics, **Assistant Professor Medicine, Govt. Medical College/Rajindra Hospital, \\ Patiala, Punjab, India, 147001 \\ Corresponding Author: Dr. Harshinder Kaur, Assistant Professor, Dept. of Pediatrics, \\ Govt. Medical College, Patiala, Punjab, India, 147001 \\ E-mail:drharshpatiala@yahoo.com
}

\begin{abstract}
The practice of female infanticide has been prevalent in almost all the societies of the world and this has been the bane of human civilization since ages. Scientific advancement has led to development of new techniques for determining the sex of the unborn child. This has given a fillip to the archaic custom of gender discrimination against the girl child who can now be easily aborted without going through the hassle of giving birth to her. The society always finds out some reasons to justify the acts of violence against the female gender. In spite of laws like the prevention of Dowry act, Domestic Violence Act and the PNDT act, there are a lot of reasons left unattended due to which the killing of the girl child is continuing. Strict implementation of various laws to protect the women in addition to tackling the reasons behind female feticide shall enable the society to get rid of the abominable practice of female feticide. The study has been able to bring to light reasons which goad the parents of the girl child to kill her in the mother's womb.
\end{abstract}

Keywords: Knowledge, attitude, female foeticide

\section{Introduction}

Though most societies agree that to protect one's infant is a basic human trait but the abhorrent practice of killing the girl child by discarding it after birth has been widely prevalent in all the world societies since the olden times. Girls have been denied the right to live and her chances of survival are curtailed by neglecting her nutritional and medical needs. Sir Jonathan Duncan in 1979 produced the first scientific evidence of the age old killing of female child in India.

The declining sex ratio in India is a matter of grave concern. The United Nations Children's Fund states that 50 million girls and women are missing from India's population aptly supported by the census figures of 2001 and 2011.(1,2) 
The entry of prenatal sex selective techniques as ultrasound and amniocentesis has given a fillip to prenatal sex selection and sex selective abortions $(3,4)$. The ultrasound has been used to find out the sex of the fetus at 12 weeks of gestation, the sensitivity for finding the male fetus is around 50 $\%$ which approaches $100 \%$ in case of diagnosis of female fetus.

The reasons that goad the parents to go for female feticide have not been properly tackled over the years. In the Indian subcontinent, son is seen as the torch bearer of the family, the practice of giving dowry to the daughters and the widely held wish of the parents to reside with their sons only in their old age are some of the reasons that perpetuate the gender discrimination and result in abandonment of the girl child and female feticide. $(5,6,7)$

The natural ratio of boys to girls is between 103107. , any number above that indicates that females are being killed in the mother's womb. According to census data collected over the years this ratio of boys to girls in the age group 0-6 years has shown an ever widening distance, 102.4 males to 100 females in $1961,104.2$ in $1980,107.5$ in 2001 and 108.9 in 2011.(1,2). Some authors (8) have argued that the disturbed sex ratio could be because of female feticide or there could be other reasons to explain this. Other scholars (9) have opined that sex ratio at birth and population sex ratios are remarkably constant when discussing the human species.
The census data has clearly shown the skewed sex ratio due to continuing killing of the girl child. The abominable decline in female sex ratio of 940 girls to 1000 males as per 2011 census(1.2) especially in the northern belt of Punjab, Haryana, Rajasthan also ,Gujarat, Maharashtra and Andhra Pradesh is creating grave social turmoil and has serious implications for the medical professionals as also a challenge to the policy makers.

\section{Materials and Methods}

The study was conducted in the Pediatric and Medicine outdoors of Rajindra Hospital attached to Govt. Medical college, Patiala, Punjab which entailed interviewing parents who came for their own or the examination of their children in the Medicine and Pediatric outdoors. A questionnaire was utilized to enquire about their knowledge and attitude towards the practice of female feticide and its effects on the society. The study was conducted from January 2016 to February 2017.

\section{Observations}

A total of 1478 women were included in the study who agreed to be interviewed regarding the practice of female feticide and its consequences on the society.

591 women $(40 \%)$ were more than 65 years, 341 (23\%) between the age group 45-65 years,369 $(25 \%)$ between 30-45 years and 177 (12\%) were less than 30 years of age.

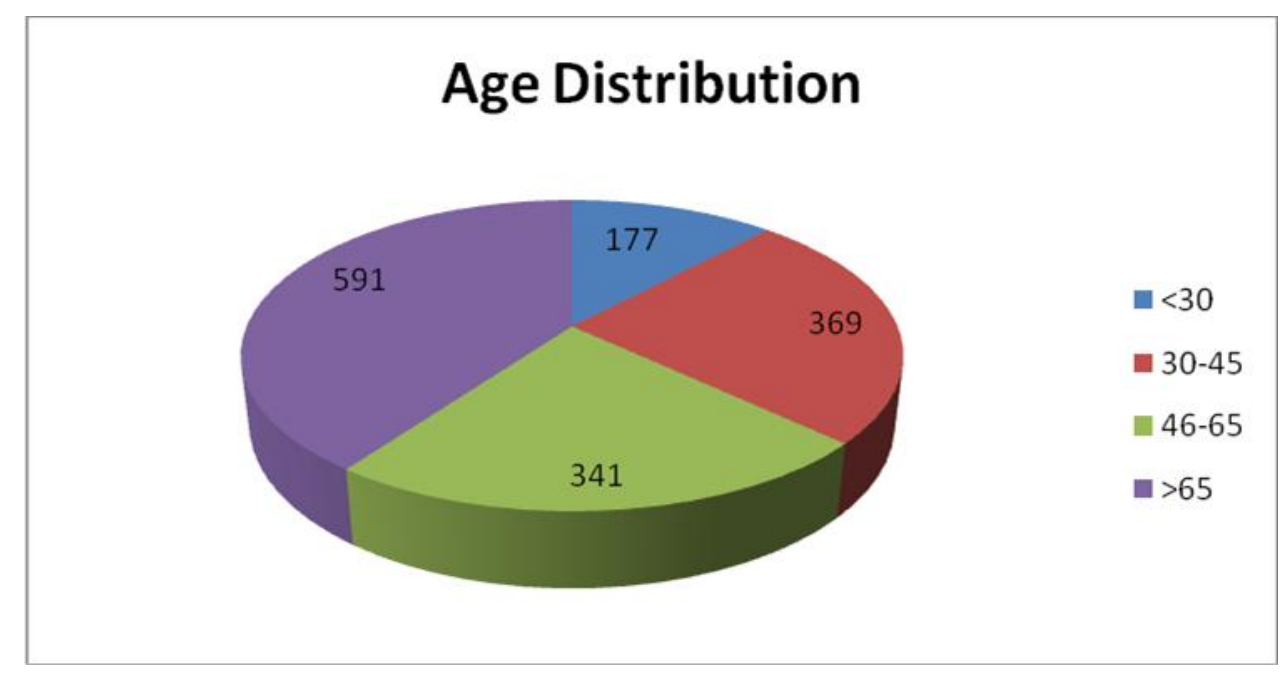

Figure1: chart showing age distribution of respondents. 
$54 \%(\mathrm{n}=798)$ of the respondents were Sikhs, 45

$\%(\mathrm{n}=665)$ were Hindus, $1.05 \%(\mathrm{n}=15)$ were

Muslims.

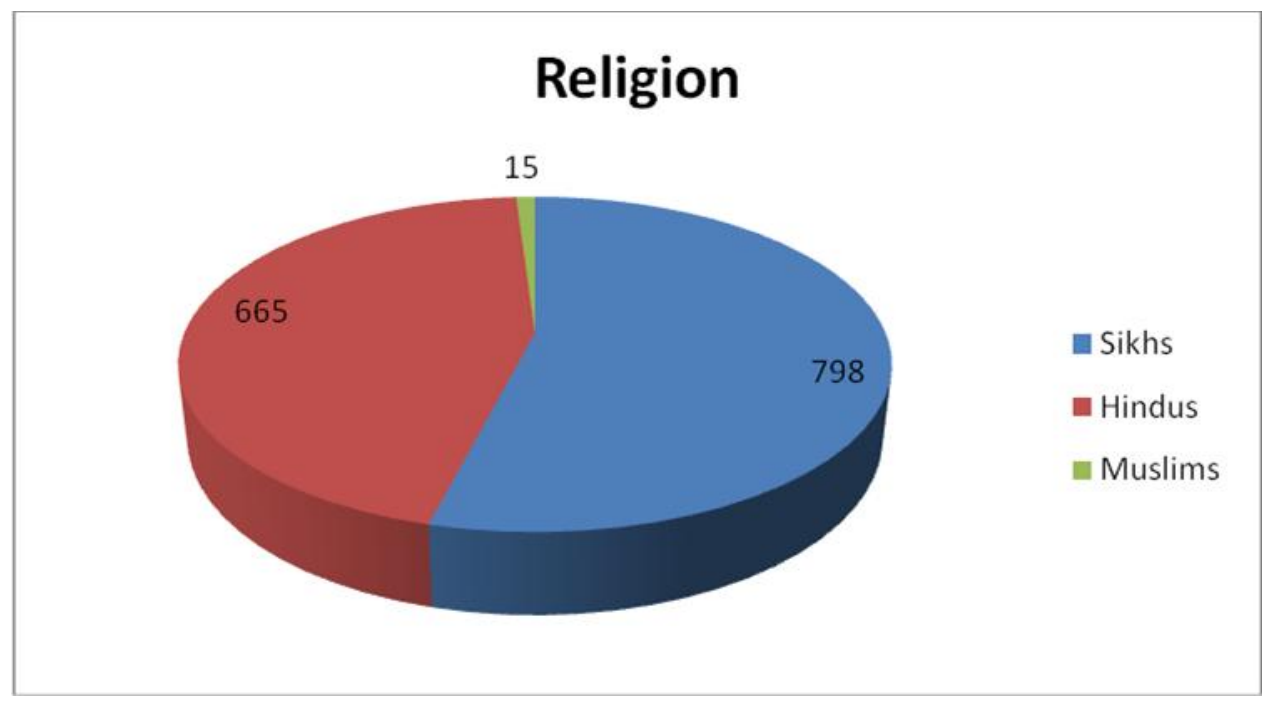

Figure 2: chart showing religion wise distribution of respondents

$86 \%(n=1271)$ of the respondents were living in rural and semi urban areas of Punjab while $24 \%$ $(n=207)$ were living in urban area.

$67 \%(n=990)$ of the women taken up for the study were under matriculates, out of them 554
$(56 \%)$ had studied for less than 5 years in school or were illiterate.26\%( $n=384)$ of the women were graduates and $7 \%(\mathrm{n}=103)$ had higher qualification.93\% $(n=1375)$ of respondents lived in joint families or extended families and only 7 $\%(\mathrm{n}=103)$ were living in nuclear households.

\section{Education Status}

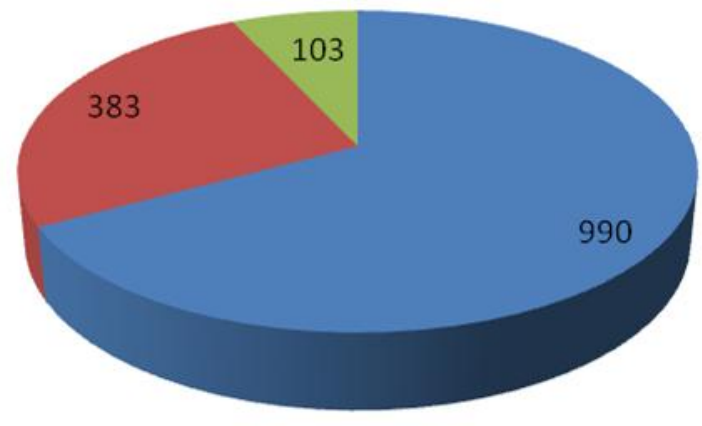

- Under Matriculate

- Graduate

wigher Qualification

Figure 3: chart showing educational status of respondents 
The sources of information about female feticide and its consequences on the society revealed that television and radio accounted as the major sources of information. $58 \%$ of the respondents $(\mathrm{n}=857)$ had acquired knowledge from watching TV and listening to radio.12\% $(\mathrm{n}=177)$ cited newspapers and $8 \% \quad(\mathrm{n}=118)$ had received information from vernacular magazines. Another $13 \%(\mathrm{n}=192)$ had acquired information by listening to various speakers at social functions and the rest, $9 \%(\mathrm{n}=134)$ had acquired knowledge from their friends, peers and health workers.

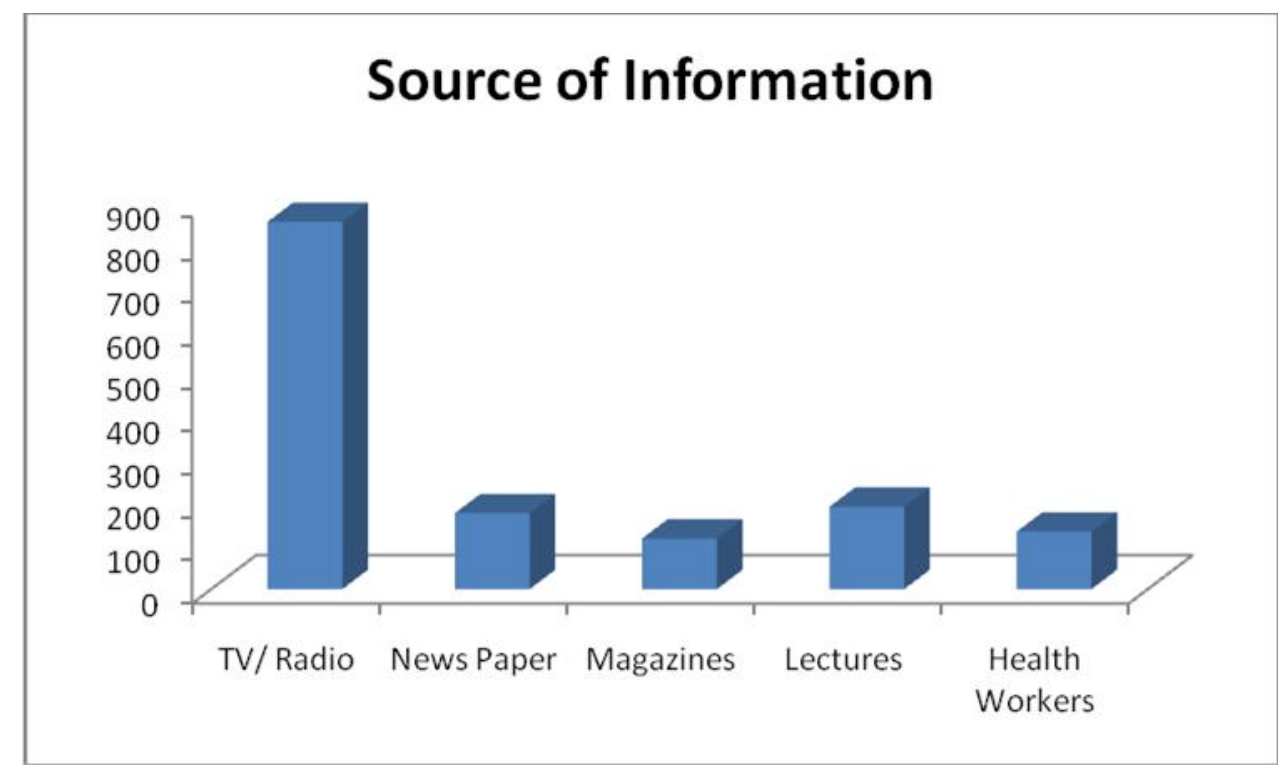

Figure 4: Bar diagram showing sources of information about female feticide

$100 \%$ of the respondents were aware of the activity of female feticide prevalent in India and especially in the states of Punjab and Haryana.54 $\%$ of the respondents $(n=798)$ were of the opinion that knowing about the sex of the child before birth by prenatal ultrasound or other techniques was justified and also that sex selective abortions targeting the female child only were justified. 38 $\% \quad(\mathrm{n}=562)$ respondents disapproved of sex selective abortions while $8 \% \quad(\mathrm{n}=118)$ were undecided.

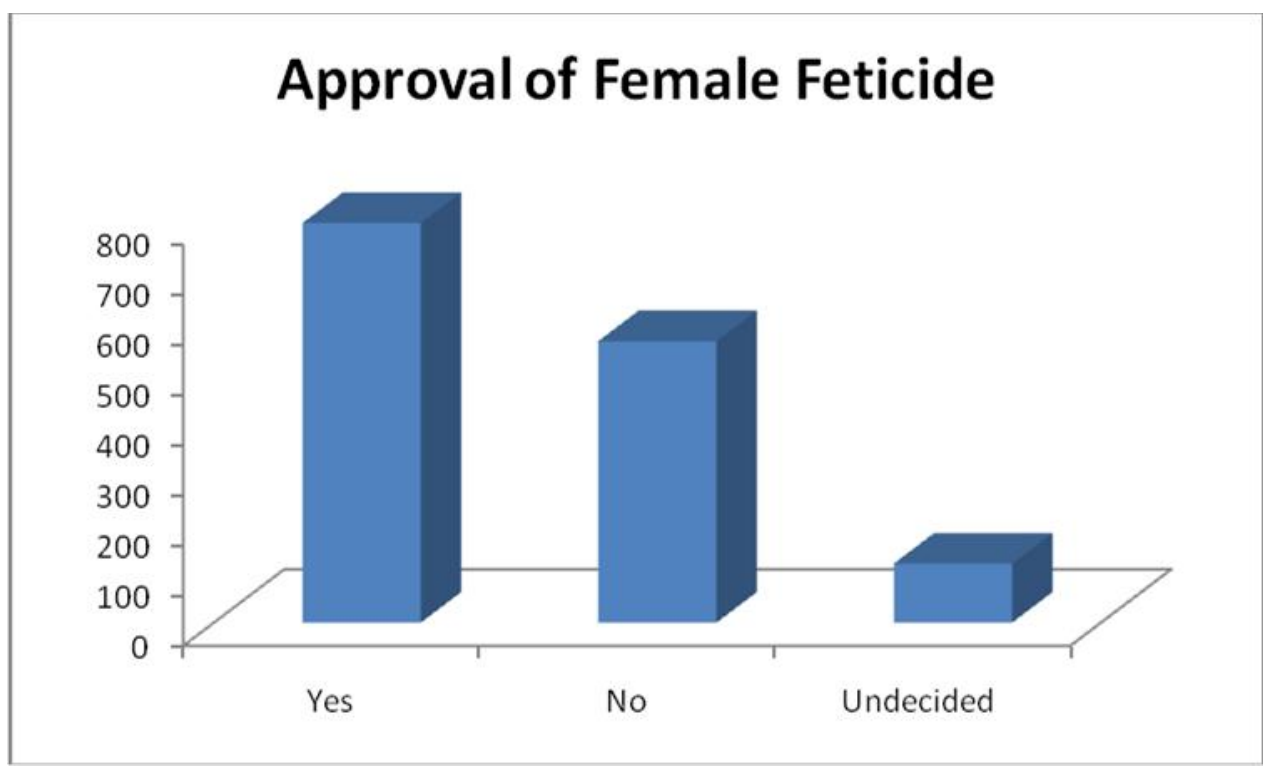

Figure 5: Bar diagram showing approval of female feticide amongst respondents 
Enquiring about the reasons $22 \%$ women( $\mathrm{n}=325)$ were afraid of torture of daughters by their in laws after marriage, $11 \%(n=163)$ ascribed dowry as the prime reason for killing the daughters. Other reasons were inability of the parents to live with their daughters in old age $(8 \%, \mathrm{n}=118)$,marriage expenses $(8 \%, \mathrm{n}=118)$,considering daughters to be a burden on the family ( $3 \%, n=44)$,division of family wealth ( $2 \%, \mathrm{n}=30)$, need for protecting the honor of the girl $(3 \%, \mathrm{n}=44)$ and $5 \%$ were of the opinion that society has denigrated and is not safe for the daughters. $38 \% \quad(n=562)$ women were afraid and wary of the rising graph of crimes against women and were of the opinion that the society has denigrated and is not safe for the daughters.

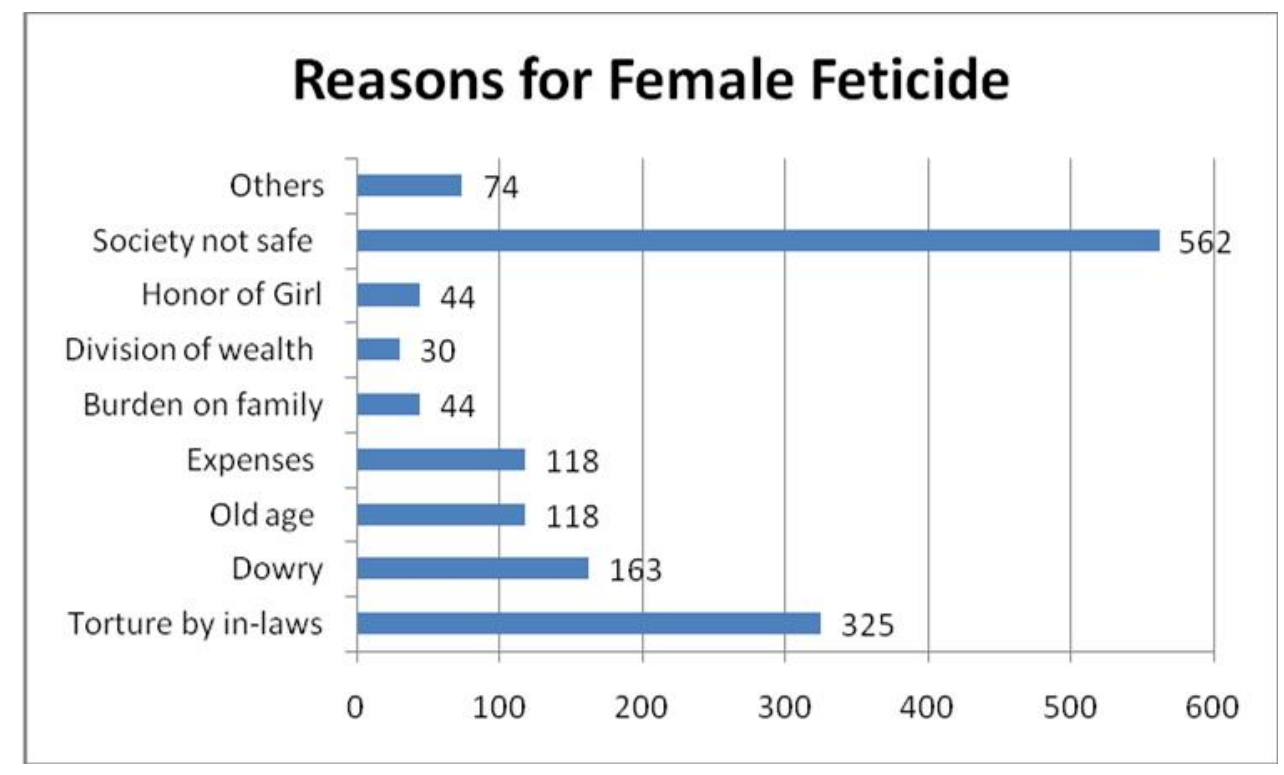

Figure 6: Chart showing the reasons of supporting female feticide given by respondents

In spite of so much stress being laid of fighting the menace of female feticide by the central and state governments, the vast majority of respondents in the present study were unaware of the impact of this practice on the society. On sustained questioning the respondents came up with answers.

$36 \%(n=532)$ women were of the opinion that decrease in the number of girls would result in difficulty in finding brides for their sons, $14.4 \%$ $(n=213)$ were of the opinion that it would result in improving the status of women in the Indian society, $13.6 \% \quad(n=201)$ of the respondents opined that crimes against women would increase, $14 \%(n=207)$ were of the opinion that this would result in decrease in the practice of dowry, $8 \%(n=118)$ thought that killing the girl child may result in decline in the status of girls. A significant percentage $(14 \%, \mathrm{n}=207)$ were unable to give any significant opinion about the effect of female feticide on the society. 
Int. J. Curr. Res. Med. Sci. (2017). 3(5): 21-28

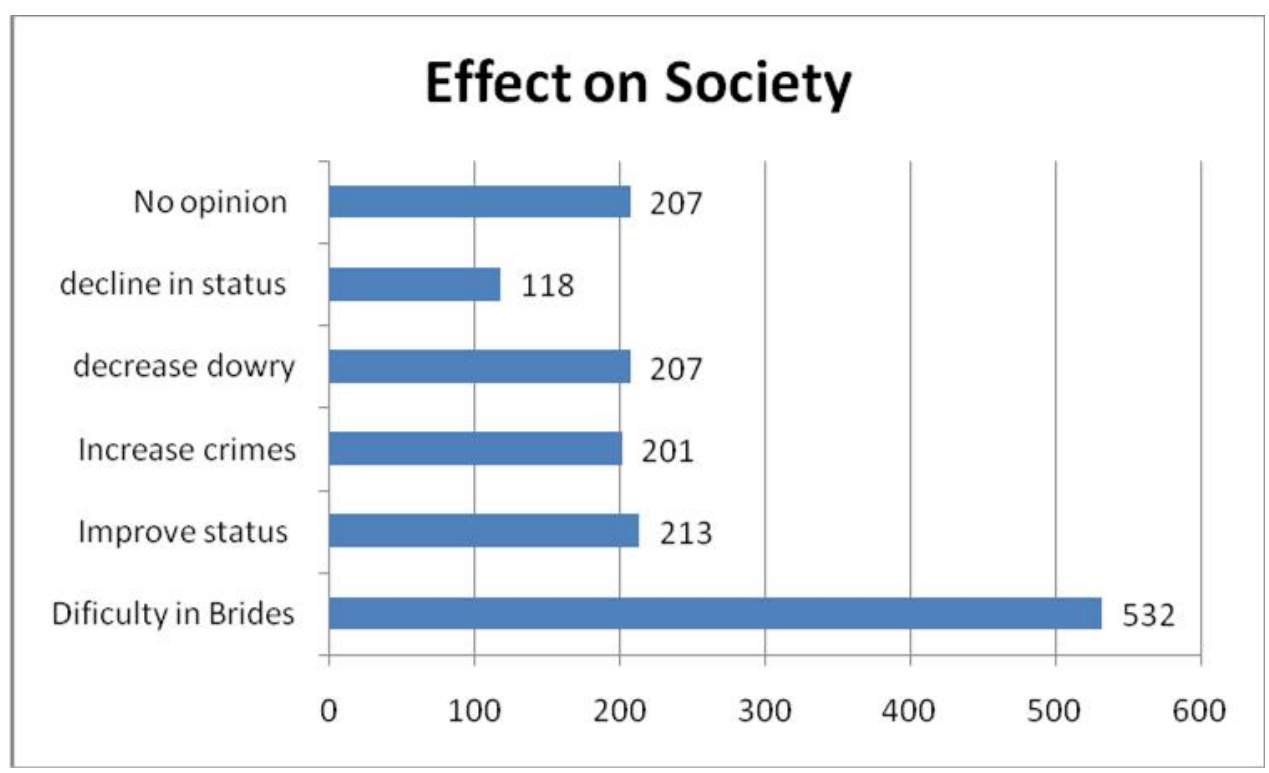

Figure 7: chart showing the possible effects on the society as given by the respondents.

\section{Discussion}

The present study was initiated to know the awareness about female feticide in the female population attending outpatient department of Pediatrics and Medicine of Govt. Medical College attached toRajindra Hospital, Patiala and to know the changing trends in the reasons, if any, to support the killing of girl child in the mother's womb.

In our study, awareness about female feticide was $100 \%$. This was irrespective of the residential and educational status of the respondents. A study by Kansal et al(10.) showed that $74.9 \%$ of women were aware of female feticide. Srivastva et al(11) in his study from Bareilly documented the awareness about feticide around $70 \%$.

The universal awareness about female feticide in our study is because of the increased media exposure about this issue in print media and audio visual media. In the present study, $58 \%$ of women had received knowledge about the issue from television and radio, while $12 \%$ from newspapers, $13 \%$ from various programs and just $9 \%$ from health workers and peers. Kansal(10 ) in his study found out that television $(53.9 \%$ ),followed by friends/relatives(36.1\%)were main sources of information. Other sources were radio $(15.7 \%)$, print media $(13.6 \%)$ and doctors/paramedics (12.6\%) This makes out the work of governmental agencies to spread word about ill effects of female feticide in a more decisive manner.

In the present study, $54 \%$ of the women were of the opinion that prenatal sex determination and sex selective abortion of the female fetus was justified. Srivastva et al(11) ,in their study documented that $35 \%$ of women justified prenatal sex determination and $20 \%$ accepted to go in for fetcide if the fetus was female. Vadera(7) revealed in his study that $20 \%$ of women would go in for female feticide if they knew the sex of the fetus. Ajinder Walia,(12) reported $41.25 \%$ of the women in his study to be supportive of female feticide if they knew the sex of the fetus.

The awareness about the impact of killing of the girl child on a massive scale was quiet poor in the present study. The various effects of the demographic change were reported as difficulty in finding brides (36\%), improvement in the status of girls $(14.4 \%)$,increase in crime rate against girls $(13.6 \%)$, decrease in the practice of dowry (14\%), and only $8 \%$ were of the opinion that wanton killing of the girl child and declining sex ratio may result in fall in the status of girls. Kansal(10 ) in his study from Meerut documented that $36.28 \%$ women opined that female feticide will result in social imbalance,34.61\% said that men would find difficulty in finding brides, 20,87 $\%$ said that families cannot be run while $8.24 \%$ said that it would result in increase in crime rate against women. 
Over the years the reasons which made the parents to kill their daughters after birth or to go in for sex selective abortions have shown a dramatic change. In our study, $38 \%$ of women were afraid of the rising crimes against women ,22\% were afraid of torture of their daughters at the hands of inlaws, $11 \%$ ascribed dowry as the main reason. Other reasons were support of parents in old age by their sons $(8 \%)$, marriage expenses of daughters $(8 \%)$, daughters considered as burden on the family (3\%) and fear of division of family wealth (2\%). Puri (6) in his study from urban slums of Chandigarh noted that dowry was the main motive of female feticide. Parents thought that girls are a burden on family and economic liability. Vadera and Joshi (7) revealed in their study that social responsibilities by sons, propogation of family name and occupation, support of parents in old age, and performance of religious rites during cremation and dowry were the reasons of son preference and female feticide. Imam Z (13) reported that $70 \%$ of all abortions performed in Delhi are terminations due to the fetus being female. This fact documents aptly the wide spread practice of killing the girl child is continuing unabated.

\section{Conclusion}

In the present study investigators assessed the knowledge of female feticide among 1478 women belonging to the state of Punjab attending the OPD of tertiary care hospital in Patiala, Punjab. $100 \%$ of the respondents were aware of the practice of female feticide, about half (54\%) were supportive of it. This is a fact of concern that in spite of so much awareness being created against the ill effects of female feticide, the public support of the practice is still unabated. The reasons goading the parents to go in for female feticide are a reflection of the denigrating society and the rising crime graph against women in the cities, villages and at the work place. These facts should be an eye opener for the policy makers.

\section{Source of funding: Nil}

Conflict of interest: None declared

\section{References}

1. Data Highlights-2001 Census, Census Bureau, Government of India

2. India at Glance-Population census 2011-Final census of India, Government of India (2013)

3. Mazza V, Falcinelli C, Paganelli S. "Sonographic early fetal gender assignment: a longitudinal study in pregnancies after in vitro fertilization". Ultrasound Obstet Gynecol.. June 2001; 17 (6): 513-6.

4. Pakrasi KB, Haldar A. sex Ratios and Sex sequences of births in India. J biosoc Sci 1971;3: 327-37.

5.Sahni M, Verma N, Narula D, Varghese RM, Sreenivas V, Pulliyel JM. Missing girls in India: infanticide, feticide and made to order pregnancies? Insights from hospitals -based sex-ratio - at -birth over the last century. PLos ONE 2008; e 2224.c2008.

6. Puri S, Bhatia V, Swami HM. Gender preference and awareness regarding sex determination among married women in slums of Chandigarh. Indian J Community Med 2007; $1: 60-2$

7. Vadera B N , Joshi U K, Unadakat S V, Yadav B S, Yadav B S, Yadav S. Study on knowledge ,attitude and practices regarding gender preference and female feticide among pregnant women . India J Community Med 2007;32:300-1

8. James W H. "Hypothesis :Evidence that mammalian sex ratios at birth are partly controlled by parental hormone levels around the time of conception. Journal of Endocrinology July2008; 198(1):3-15.

9. Therese Hesketh and Zhu Wei Xing. Abnormal sex ratios in Human Populations :causes and consequences, PNAS, September 2006;103(36): 13271-75.

10. Kansal R, Maroof KA, , Bansal R, Parashar P. A hospital -based study on knowledge, attitude and practice of pregnant women on gender preference,prenatal sex determination and female feticide. India J Public Health $2010 ; 54$ :209-12.

11.Srivastav Shalini ,Kariwal P, kapilasrami MC, National Journal of Community Medicine, July-Sept 2011, 2(2):273-76. 
12. Walia A. Female feticide in Punjab:Exploring the socioeceonomic and cultural dimensions, Idea J 2005;32:300-1.

13.Imam Z ,India bans female feticide, BMJ 1994; 309:428 (Pubmed) (Full Text )

\begin{tabular}{|c|l|}
\hline \multicolumn{2}{|c|}{ Access this Article in Online } \\
\hline Q & Website: \\
& www.ijcrims.com \\
\cline { 1 - 1 } & Subject: \\
Quick Response Code & \\
\hline
\end{tabular}

How to cite this article:

Harshindar Kaur, Gurpal Singh Sachdeva. (2017). A Study to assess the knowledge and Attitude about Female Feticide among women attending outpatient department in a tertiary care hospital Punjab. Int. J. Curr. Res. Med. Sci. 3(5): 21-28.

DOI: http://dx.doi.org/10.22192/ijcrms.2017.03.05.005 